\title{
Can WhatsApp facilitate interaction? A case study of adult language learning
}

\author{
Dimitrios Vogiatzis, Koula Charitonos, Korina Giaxoglou \\ and Tim Lewis
}

\section{I Introduction}

The ubiquity of technology and the proliferation of digital technologies in our everyday life have transformed the landscape of education. Technological developments in the 21 st century provide opportunities for inclusion and access to a wide range of information, knowledge, and learning. Consequently, today, technology significantly contributes to educational environments in which emerging digital tools are used to facilitate teaching and learning in several ways. The advent of Mobile Instant Messaging application (MIM) like WhatsApp has influenced the ways in which people communicate in everyday life and caught scholarly attention in exploring their potential in language learning settings.

Chapter 4 presents an exploratory case study undertaken in an adult education centre and aims to examine the extent to which WhatsApp can be used as a means of facilitating learner-to-learner and teacher-to-learner interactions. In line with the purpose of this book, Chapter 4 explores the practical applications of WhatsApp and aims to identify the "enablers" and "disablers" of this MIM app for language learning and interaction.

\section{I.I Literature review}

The advent of MIM applications like WhatsApp has shaped the communicative practices of people around the globe, as also indicated in Chapter 16 (Srisontisuk, 2022). These mobile communication services differ from traditional SMS, since they enable users to send and receive text messages, images, video, audio, and location information in real-time to individuals or groups of friends at no cost (Church $\&$ de Oliveira, 2013). WhatsApp is an internet-based cross-platform instant messaging application for smartphones (also accessible via desktop computers, laptops, and tablets). To date, WhatsApp is the most popular MIM application with two billion monthly active users worldwide (Statista, 2020). 


\section{I.2 WhatsApp as a language learning environment}

The popularity growth of WhatsApp and its features has led many scholars to explore its potential in language learning settings. Specifically, this MIM app was used to develop language learners' writing (Ahmed, 2019) and reading skills (Alzubi \& Singh, 2018), as well as their vocabulary acquisition (Lai, 2016) and listening skills (Fauzi \& Angkasawati, 2019). A recent systematic literature review conducted by Kartal (2019) explored the effectiveness of WhatsApp and identified 37 studies in the field of language learning and teaching. The review concluded that WhatsApp is a useful tool that can facilitate language learning, but highlighted that the studies examined did not clearly discuss the theoretical underpinnings of WhatsApp use. Moreover, according to Kartal (2019), some of the articles analysed provided neither any information about the levels of participation in the online environment nor any details about the implementation process.

In terms of methods, the studies examined relied heavily on quantitative data (questionnaires and pre- and post-tests), while only two studies used observation techniques to investigate participants' actual use of WhatsApp for language learning. This shows that there is a lack of measurements such as observation of participants' online activities and analyses of their sharing practices. Empirical frameworks for the analysis of sharing practices in Social Network Sites (SNS), as proposed by Androutsopoulos (2014), can capture learners' actual participation in these online environments (see Section 4.3.3).

As regards the educational settings in which WhatsApp has been implemented, the review showed that most of the studies $(65 \%)$ were conducted in higher education contexts, while none of them examined the effects of WhatsApp in adult education. Adult and community learning is a different environment from higher education in important respects. Learners are more mature (often of retirement age), and they are studying purely for personal interest, rather than formal qualifications. Consequently, their learning is not assessed or graded, while they are much less exposed to the target language than they would be at university.

\section{I.3 WhatsApp and language interaction}

Interaction is considered one of the main mechanisms by which languages are learnt (Mackey et al., 2012), as also indicated in Chapter 5 (Conde Gafaro, 2022) and Chapter 6 (Chua, 2022). Specifically, Aburezeq and Ishtaiwa (2013) examined the impact of WhatsApp on interaction in an Arabic language teaching course. The findings indicated that most participants (71\%) perceived that WhatsApp had the power to enhance peer-to-peer interactions. However, this study relied on interview data and did not provide any empirical evidence on how WhatsApp can facilitate such interactions. As regards student-to-student interactions, Keogh (2017) argued that WhatsApp can increase learners' involvement and accommodate various traits of communities of practice (i.e., co-construction of knowledge, scaffolding, etc.). Nevertheless, this study revealed that there was "a lack of true 
dialogue" when learners interacted with each other, while most of the discussion on WhatsApp were teacher-initiated (Keogh, 2017, p. 102).

Another study examined the benefits of WhatsApp to develop second language writing (Andujar, 2016). Findings indicate that WhatsApp contributed to the development of accuracy in second language writing. As regards interaction, Andujar (2016, p. 63) argued that "WhatsApp constitutes a powerful educational tool to encourage second language interaction among participants" and emphasised the need for further research mentioning that "[i]ts tremendous potential to activate students' involvement remains one of the least exploited functionalities of mobile phones".

\section{I.4 Aims of the study and research questions}

In line with the literature discussed above, Chapter 4 places attention on the opportunities that this MIM application can provide in terms of learner-to-learner and teacher-to-learner interaction (including peer-to-peer feedback interaction). Specifically, the study presented in Chapter 4 seeks to address the following research questions:

1 How do adult learners and their teacher participate and contribute while using WhatsApp for language learning purposes?

2 To what extent can the use of WhatsApp facilitate (or impede) language learning interaction in an adult education context?

\subsection{Research context and methods}

This study explored the use of WhatsApp by a group of adult learners of German language in an adult education centre in the UK. In this context, learners attended classes once a week (90 minutes to two hours), running for three terms of ten weeks each (September-December, January-April, April-July, 2019-2020). Adult learners in this school typically attended 30 lessons a year (2 hours a week) and were exposed to the target language only intermittently, while the long breaks between the terms made it difficult for them to recall and assimilate knowledge. WhatsApp use in this study aimed to alleviate these challenges by extending the limited class time and providing a friendly online environment that could facilitate learner-to-learner and teacher-to-learner interactions.

\subsection{Choice of technology and implementation process}

The selection of the MIM was made by considering teachers and learners' needs and preferences, as well as their familiarity with the various MIMs available today. A WhatsApp group was created by the teacher, and learners were invited to join the group. The first author was also added as member of the group with the sole aim of observing and recording interactions amongst the members of the group without disturbing the naturally occurring exchanges. Given that one of the aims 
was to examine how the teacher and learners adapted to WhatsApp and impulsively used it to facilitate their language teaching and learning, respectively, no formal rules were set by the researcher. Participants were given complete freedom to interact, initiate conversation, and share any information related to their German language learning.

\subsubsection{Participants' profiles}

Participants were eight native speakers of English who aimed to learn German as a foreign language purely for personal interest. All learners were adults and fell into a range of age categories, while two were in the age range of 40-49. As identified in Chapter 19 (Iwaniec-Thompson, 2022), six learners were in the older category, two in 50-59, respectively, three in 60-69 years old, and one participant being over 70 years old.

\subsubsection{Data collection and analysis}

The research reported in Chapter 4 is part of a broader $\mathrm{PhD}$ thesis that followed a mixed-methods approach, employing pre- and post-questionnaires, combined with online observations and interviews. In Chapter 4, we explore the ways in which online interactions took place in the WhatsApp group by examining the data derived from the online observations and the semi-structured interviews.

Throughout the duration of the study ( $n=22$ weeks), systematic online observations were performed, and all participants' posts and comments were archived and analysed to develop an in-depth understanding of informants' online participation. Androutsopoulos' (2014) empirical framework for the analysis of sharing practices in SNSs was adapted and used for the purposes of this study. The analysis was carried out in three stages.

First, a quantitative analysis of participants' online contributions was carried out. Aiming to examine the extent to which the learners and the teacher participated and contributed to the WhatsApp group, all chat entries were counted, as also described in Chapter 10 (Chua, 2022). A chat entry was identified when a participant published a message in the text-chat window (Cho, 2017), including typed text, embedded images, videos, YouTube videos, emojis, links to web content, or a combination thereof. Counting and coding the chat entries in this online environment distinguishes between initiating and responding contributions (Androutsopoulos, 2014). An initial entry was identified when a participant published a message to initiate conversation on a new topic, while a chat entry was categorised as a responsive contribution when a participant replied to an initial entry within the online environment.

The second step involved the identification and selection of relevant communicative events (or "significant moments", the term used in Androutsopoulos, 2014), which were then qualitatively analysed. As proposed in Androutsopoulos (2015) the basic unit of analysis is not a single post but a communicative event which is defined as a "spatially and temporally delimited, multi-authored sequence of 
contributions" (Androutsopoulos, 2014, p. 7) and consists of an initial chat entry followed by other users' responsive contributions. To identify and select communicative events relevant to the analysis, three criteria were followed, namely (1) "repetition", (2) "responsiveness", and (3) "reflexivity" (see Androutsopoulos, 2014, p. 8). More specifically, repetition involved those communicative events in which participants repetitively used similarly styled chat entries. Events in terms of responsiveness were identified when posts receive a significant number of responses by the networked audience. Finally, reflexivity included communicative events where participants self-reflect upon their sharing practices. Such reflections are "elicited in secondary data sources such as interviews" which can "offer important pointers back to acts of sharing in the digital data" (Androutsopoulos, 2014, p. 8).

The third stage involved a qualitative analysis of the selected communicative events aiming to provide an empirically evidenced account of how WhatsApp was used as means of facilitating participants' language learning in this adult education setting. As proposed in Androutsopoulos (2014), this qualitative analysis was performed on three different levels, namely, "selecting", "styling", and "negotiating". Selecting concerns what participants chose to share and why, while styling involved the entextualisation of what was shared (i.e., how participants style their content), and negotiating deals with the audience engagement (i.e., how participants negotiate what is shared with other users) (see Androutsopoulos, 2014, p. 8). It is worth noting that "sharing" in SNSs is conceptualised as a mode of participation that incorporates both communication (where sharing is "telling") and distribution (i.e., sharing digital content) (see John, 2013).

Finally, after the completion of the study, semi-structured interviews $(n=6)$ were conducted to provide more insight into the results derived from the online data and to identify the reasons why learners demonstrated specific participation patterns in the online environment. The interview data were subjected to thematic analysis following the six steps proposed by Braun and Clarke (2006).

\subsection{Results}

\subsection{Participation and sharing practices in WhatsApp}

As Table 4.1 shows, the learners and their teachers made a total of 243 chat entries. Approximately one-third of chat entries $(n=78,32.1 \%)$ were made by the teacher, emphasising that his contribution in initiating, coordinating, and participating in other interactions was key. Apart from the individual messages, the teacher made 22 (56.4\%) initial entries and replied to $56(27 \%)$ of the posts. These findings suggest that the teacher had a central role in the WhatsApp group.

Moreover, as Table 4.1 illustrates levels of participation among the learners varied. One learner, Emma, was very active in the online environment posting 52 out of 243 chat entries (21.4\%), while others like Petra and Klaus were more passive posting six and only one chat entry, respectively. As regards learners' contribution, the data made clear that their participation in the WhatsApp group was reactive, rather than proactive. Specifically, learners rarely took the initiative to start a new 
Table 4.I Level of participation and contribution

\begin{tabular}{lcccccccccc}
\hline & Teacher & Emma & Louisa & Otto & Frieda & Jürgen & Helmuth & Petra & Klaus & Total \\
\hline $\begin{array}{l}\text { Individual } \\
\text { chat }\end{array}$ & 78 & 52 & 27 & 23 & 20 & 19 & 17 & 6 & 1 & $\mathbf{2 4 3}$ \\
$\begin{array}{c}\text { entries } \\
\begin{array}{l}\text { Initial } \\
\text { Entries }\end{array}\end{array}$ & 22 & 9 & 1 & 2 & 3 & 2 & 0 & 0 & 0 & 39 \\
\begin{tabular}{l} 
Replies \\
\hline
\end{tabular} & 56 & 43 & 26 & 21 & 17 & 17 & 17 & 6 & 1 & $\mathbf{2 0 4}$ \\
\hline
\end{tabular}

topic as the number of initial entries per learner was very low, while most of their contributions (89.7\%) were replies to previous conversations or activities posted by the teacher. The reactive nature of learners' participation was obvious from the early stages of the intervention. A possible reason that elucidates learners' reactive participation emerged from the analysis of the interview data. Specifically, all learners felt that they did not "have the right or the authority to initiate something so we [they] sit back wait for [name of the teacher] and then we respond" (Louisa). The view that only the teacher had the authority to initiate conversation in the online environment points out the different dynamics of participating and sharing when using WhatsApp for language learning purposes. It seems that this was a rule set by learners arbitrarily, as it was never formally set. Instead, learners were given complete freedom to interact, initiate conversations and share any information they wanted on WhatsApp, but opted for reproducing the participation dynamics of classroom interaction in this digital context.

\subsubsection{Activities in the WhatsApp group}

A total of twelve language learning activities were uploaded by the teacher. Half of them were writing tasks that required the learners to compose sentences using vocabulary and/or verbs supplied by the teacher, while three activities asked learners to describe their weekend using the target language. The teacher also uploaded another activity asking the learners to plan a trip to Germany discussing its practicalities (where to go, what to do, what to see, when to go and for how long), while another activity required learners to compose a dialogue in a restaurant or a shop. Finally, an activity shared by the German teacher asked learners to choose and describe a city in Germany or Austria for their peers to guess which it was.

Three of the activities presented above were chosen and qualitatively analysed following the selection criteria (i.e., repetition, responsiveness, and reflexivity) as discussed in Section 4.2.3 Specifically, the first communicative event satisfied the first criterion (i.e., repetition) and offered a representative example of the activities which were repetitively used by the teacher. The second event (see Section 4.3.4) was selected because it received the most significant number of responses by the learners (i.e., responsiveness), while the third communicative event (see Section 4.3.5) entailed participants' self-reflection upon their sharing practices in the online environment (i.e., reflexivity). 


\subsubsection{Example I: "Constructing a sentence using the verb zutreffen auf"}

The first communicative event offers a representative example of how the teacher used the messaging application to distribute writing tasks. As Figure 4.1 illustrates, the teacher posted a writing task asking the learners to construct a sentence using the separable verb zutreffen auf (apply to). Three learners, Louisa, Frieda and Emma, followed the instructions provided by the teacher and generated sentences using the suggested verb. The teacher did not share any follow-up comments, possibly waiting for the rest of the learners to provide their answers to the writing task. After three days, he posted a text entry thanking the learners who participated in this activity and affirming that they understood the given verb well. His chat entry marked the end of this communicative event.

\begin{tabular}{|c|c|}
\hline 15 MARCH 2019 & \\
\hline $\begin{array}{l}\text { Teacher } \\
\text { Kann jemand das trennbare Verb } \\
\text { 'zutreffen auf' in einem Satz } \\
\text { benutzen? }\end{array}$ & $\begin{array}{l}\text { Teacher: Can anyone use the } \\
\text { separable verb 'apply to' in a } \\
\text { sentence? }\end{array}$ \\
\hline $\begin{array}{l}\text { Louisa } \\
\text { Regulierung wird auf alle Bürger } \\
\text { zutreffen. }\end{array}$ & $\begin{array}{l}\text { Louisa: (Emoji) Maybe ...? The } \\
\text { new regulation will apply to all } \\
\text { citizens. }\end{array}$ \\
\hline $\begin{array}{l}\text { Frieda } \\
\text { Was hat auf uns dann zugetroffen, } \\
\text { trifft nun auf Ihnen zu. }\end{array}$ & $\begin{array}{l}\text { Frieda: What happened to us then } \\
\text { applies to you. }\end{array}$ \\
\hline $\begin{array}{l}\text { Emma } \\
\text { Die Einwände der Britische Regierung } \\
\text { gegen den sogenannten Backstop, } \\
\text { dass der Backstop teilt Nordirland } \\
\text { von dem Rest Großbritanniens, } \\
\text { zutrefft genau auf der } \\
\text { vorgeschlagenen Zolltarife, die die } \\
\text { Britische Regierung kündigte an, die } \\
\text { zutreffen auf im Fall einen } \\
\text { No-Deal-Brexit. } 6\end{array}$ & $\begin{array}{l}\text { Emma: The British government's } \\
\text { objections to the so-called } \\
\text { backstop that the backstop } \\
\text { divides Northern Ireland from the } \\
\text { rest of the United Kingdom are } \\
\text { accurate on the proposed tariffs } \\
\text { that the British government } \\
\text { announced that it would apply in } \\
\text { the event of a no-deal Brexit. } \\
\text { (Emoji) }\end{array}$ \\
\hline 18 MARCH 2019 & \\
\hline $\begin{array}{l}\text { Teacher } \\
\text { Vielen Dank , und : Ihr } \\
\text { habt das Wort gut verstanden! 绝 }\end{array}$ & $\begin{array}{l}\text { Teacher: Thank you (Louisa), } \\
\text { (Frieda) and (Emma). You } \\
\text { understood the word well! } \\
\text { (Emoji) }\end{array}$ \\
\hline
\end{tabular}

Figure 4.I Example of a writing task posted by the teacher. 
Teacher

A new activity this week.. Choose a destination in Germany or Austria but don't tell the rest of the group. Imagine you're going to travel there. Write to the group describing its geographical location, how you will travel, what is special about this place and why you suggested it. The rest have to guess where it is.

Here goes...

Die Stadt liegt im Norden

Deutschlands. Ich werde dorthin fliegen. Die Stadt ist zugleich Stadt und Bundesland. Ich habe diese Stadt gewählt, weil ich als Student da war, und immer nicht Freunde dort habe.

Wo werde ich sein?

Helmuth

Es ist Hannover? 11:53

Frieda

Ich glaube, dass die beiden von Hamburg und Bremen Bundeslände sind, und also ist sie eine dieser Städte?

Helmuth

Ich bin beantworten falsch, aber Hannover war ein Stadt und Bundeslände für 92 Tages einmal $\because$

Frieda

Emma

Diese Stadt könnte entweder Hamburg oder Bremen sein. Ich glaube, dass Bremen keinen großen Flughafen hat. Daher wähle ich Hamburg $13: 09$
Teacher:

A new activity this week... Choose a destination in Germany or Austria but don't tell the rest of the group. Imagine you're going to travel there. Write to the group describing its geographical location, how you will travel, what is special about this place and why you suggested it. The rest have to guess where it is. Here goes...

The city is in the north of Germany. I will fly there. The city is both a city and a federal state. I chose this city because I was there as a student and always have friends there. Where will I be? (emoji)

Helmuth:

Is it Hanover?

Frieda:

I think that Hamburg and Bremen are federal states, so is it one of those cities?

Helmuth:

I'm answering wrong, but Hanover was a city and a state for 92 days once (emoji)

Frieda:

(emoji)

Emma:

This city could be either Hamburg or Bremen. I don't think Bremen has a big airport. That's why I choose Hamburg (emoji)

Figure 4.1 (Continued) 


\begin{tabular}{|c|c|}
\hline $\begin{array}{l}\text { Teacher } \\
\text { Keiner hat bisher richtig } \\
\text { geantwortet...! } \odot\end{array}$ & $\begin{array}{l}\text { Teacher: } \\
\text { No one has answered correctly so far...! } \\
\text { (emoji) }\end{array}$ \\
\hline $\begin{array}{l}\text { Frieda } \\
\text { Es muss Berlin sein - die dritte Stadt, } \\
\text { die auch ein Bundesland ist? }\end{array}$ & $\begin{array}{l}\text { Frieda: } \\
\text { It must be Berlin -the third city that is } \\
\text { also a federal state? }\end{array}$ \\
\hline $\begin{array}{l}\text { Jürgen } \\
\text { Vielleicht Bremen? }\end{array}$ & $\begin{array}{l}\text { Jürgen: } \\
\text { Maybe Bremen? (emojis) }\end{array}$ \\
\hline $\begin{array}{l}\text { Frieda } \\
\text { Sie hat man schon vorgeschlagt - } \\
\quad \text { ip hat 'nein' gesagt. }\end{array}$ & $\begin{array}{l}\text { Frieda: } \\
\text { It has already been suggested - (name } \\
\text { of the teacher) said 'no'. }\end{array}$ \\
\hline $\begin{array}{l}\text { Jürgen } \\
\text { Es tut mir leid! } \quad 18: 42 \\
\end{array}$ & $\begin{array}{l}\text { Jürgen: } \\
\text { I am sorry! }\end{array}$ \\
\hline $\begin{array}{l}\text { Frieda } \\
\text { Mir auch! 18:43 }\end{array}$ & $\begin{array}{l}\text { Frieda: } \\
\text { Me too! }\end{array}$ \\
\hline $\begin{array}{l}\text { Emma } \\
\text { Ja es muss Berlin sein, ich vergesse } \\
\text { immer die 'neue' Länder unseren } \\
\text { östlichen Gebrüder }\end{array}$ & $\begin{array}{l}\text { Emma: } \\
\text { Yes, it has to be Berlin, I always forget } \\
\text { the 'new' countries to our eastern } \\
\text { brothers }\end{array}$ \\
\hline $\begin{array}{l}\text { Teacher } \\
\text { Sehr gut alle! hat Bremen } \\
\text { erwähnt, und hat richtig } \\
\text { geahnt. Bremen ist es! } \text { \& Wer ist } \\
\text { jetzt dran? } \because\end{array}$ & $\begin{array}{l}\text { Teacher: } \\
\text { Very good everyone! (Emma) } \\
\text { mentioned Bremen and (Jürgen) } \\
\text { guessed right. Bremen is it! (emoji) } \\
\text { Who is it now? (emoji) }\end{array}$ \\
\hline
\end{tabular}

Figure 4.1 (Continued)

As regards learners' engagement, Figure 4.1 shows that they responded to the writing task but engaged in no other type of peer-to-peer interaction. In all six writing tasks uploaded by the teacher, the learners followed the same participation pattern, i.e., sharing their answers individually and responding directly to the teacher.

\subsubsection{Example 2: "Guess the city"}

The second communicative event "Guess the city activity" presented a different type of activity, which was selected because it received a significant number of responses from the learners (i.e., responsiveness). In this activity, each learner was asked to describe a city in a German-speaking country for others to guess which city it was (see Figure 4.2). Seven (out of eight) learners were engaged in this activity who posted a total of 32 individual chat entries. Out of all WhatsApp activities, the "Guess the city" activity was the one generating the higher number of responses from the learners. The teacher also participated in this communicative event by sharing another 27 chat entries to praise learners' effort $(n=2)$, to prompt them to describe their city $(n=3)$ and to provide 


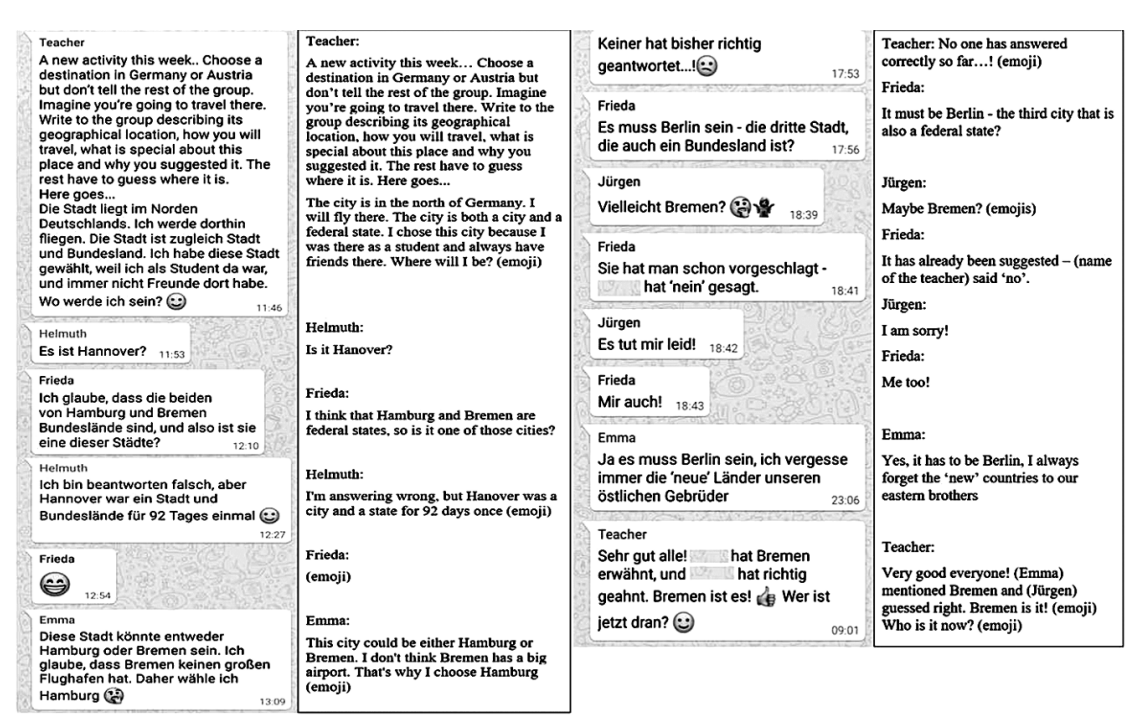

Figure 4.2 "Guess the city activity" (part I).

feedback to their contributions $(n=22)$. Overall, a total of 59 individual chat entries were made in this activity, which lasted for nine days. Due to the length of this communicative event, in Chapter 4 we provide two of its parts. The first part (see Figure 4.2) concerned how the teacher structured and initiated the activity and showed how the learners engaged with the teacher's initial post. The second part (see Figure 4.3) involved one of the learner's description of a city and his peers' contributions.

In this communicative event, the teacher posted the instructions of the activity using English and then shared a description of his selected city in German. This activity caught learners' attention and nine minutes after the teacher's initial post, Helmuth replied and made a guess regarding the city described by the teacher. In response to the teacher's post, four learners (Helmuth, Frieda, Emma and Jürgen) used the target language and tried to identify the correct city. Learners also tried to negotiate and renegotiate to reach an answer by sharing their own interpretation of the clues and using their knowledge to argue for or against a suggested answer (see Figure 4.2). Once all the learners shared their guesses, the teacher revealed the correct answer and used a thumbs-up emoji gesture indicating approval of their efforts. The teacher ended this online exchange by prompting the learners to describe their city "Wer ist jetzt dran?" (whose turn is it now?).

Following the teacher's prompt, Otto took the initiative and shared a description of his city (see Figure 4.3). Frieda made a guess about the city in question, which however was not the right one as indicated by Otto. Once he provided more information about his selected city, Emma followed-up with another guess, which Otto confirmed was the correct one.

Overall, this activity encouraged learners to read their peer's contributions, identify the clues provided and then guess the city. It also allowed them to interact with each other. 


\subsubsection{Example 3: "Your Bank Holiday weekend"}

The third communicative event concerned another activity posted by the teacher and involves learners' self-reflection upon their sharing practices in the online environment (i.e., reflexivity) which emerged from the interview data. To begin with, three (out of twelve) of the activities uploaded by the teacher required learners to provide peer-feedback. Specifically, the teacher asked learners to comment on their peers' sentences and/or correct them. It was observed that even if the learners replied individually to the activities, none of them left any comments related to the learners' language use in any of the chat entries posted by the learners. As Figure 4.4 shows, the teacher instructed the learners to describe what they had done over the bank holiday weekend, including a clear prompt for the learners to comment on each other's contributions and/or correct them. The teacher further stated that he would also provide feedback to the learners' contributions. The teacher followed the same pattern in all activities that required peer-feedback, and

Otto
Diese Stadt liegt in der Mitte
Deutschlands. Es ist bekannt für
seine barocken Gebäude und der
Dom hat das Grab des Heiligen
Bonifatius - ein großer Hinweis! Man
muss zuerst nach Frankfurt fliegen
und dann mit dem Zug fahren.

Und - ich habe diese Stadt vor vielen Jahren mit meinem deutschen Freund besucht.

\section{Frieda}

Könnte sie Köln sein?

Otto

Nein- Es ist kleiner als Köln und liegt nordöstlich von Frankfurt.

\section{Emma}

Der heiligen Bonifatius stammte aus Der Grafschaft Devon, ein einheimischer Sankt, na so was. So, muss die Stadt Fulda sein. Ich war bisher nie dort 13:58

Otto

Ah richtig Peter!

\section{Otto:}

This city is in the middle of Germany. It is known for its baroque buildings and the cathedral has the tomb of Saint Boniface - a big hint! You have to fly to Frankfurt first and then take the train.

And - I visited this city with my German friend many years ago.

Frieda:

Could it be Cologne?

Otto:

No - it is smaller than Cologne and is located northeast of Frankfurt.

Emma:

Saint Boniface came from the county of Devon, a local Saint. So, the city must be Fulda. I've never been there before

Otto:

Ah right (name of the student)!

Figure 4.3 "Guess the city activity" (part 2). 


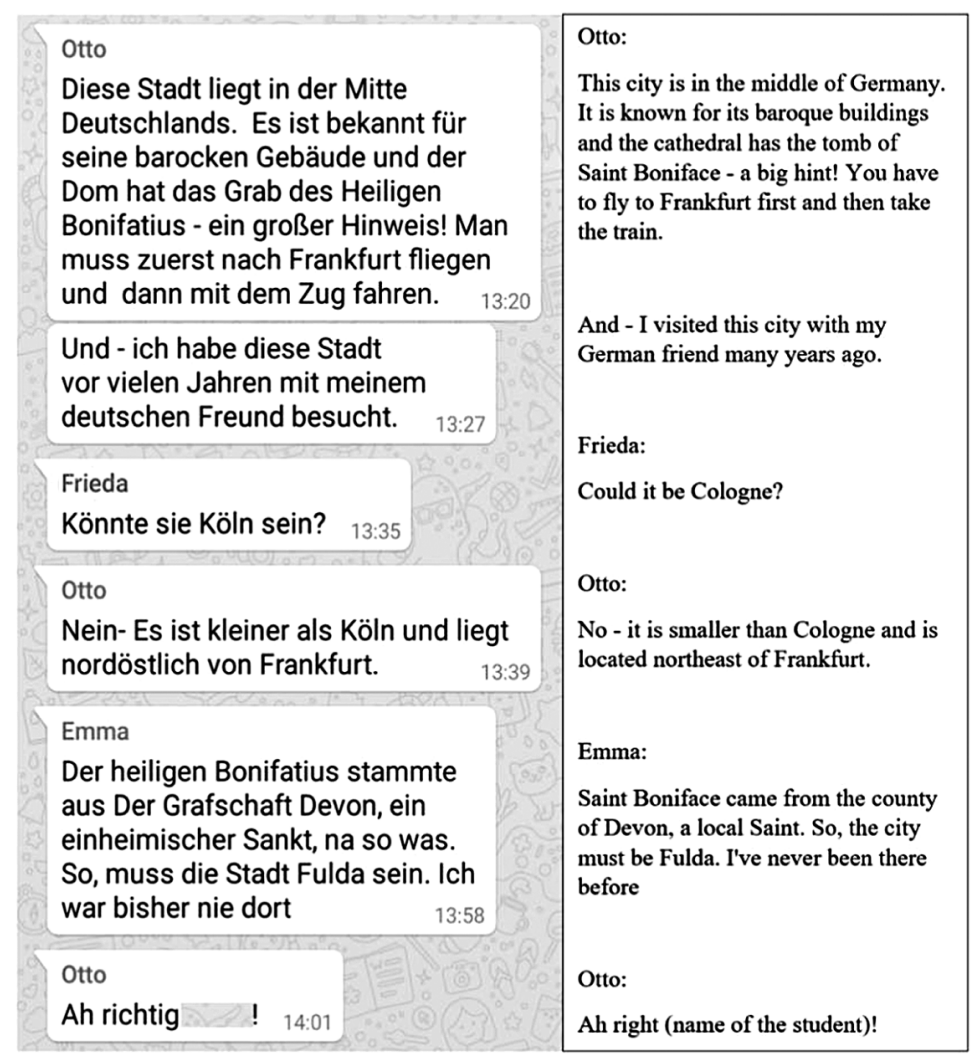

Figure 4.3 (Continued)

Figure 4.4 provides a representative example of how the teacher structured and initiated these activities.

Two days after the initial post Jürgen replied to the activity by sharing a picture of him and Helmuth who were having holidays in Berlin. Louisa and Otto shared a chat entry in response to Jürgen's picture, and three days later, Louisa replied to the activity by describing what she had done over the bank holiday weekend. The teacher then followed up with a comment related to the uploaded picture, thanking Jürgen and Helmuth for sharing, and prompting the learners to discuss their trip in Germany during their in-classroom lesson. Emma was the last learner to reply to the activity by describing what she had done during the bank holiday.

As shown in Figure 4.4, the learners partially followed the task instructions and their contributions were limited to providing individual answers to the activity. The teacher gave time to the learners to comment on their peers' contribution and when this did not happen, eight days after the initial post he provided feedback to the ones who participated in this. Similar to this activity, all the other activities of this type did not involve any peer-feedback, indicating that the learners in this study demonstrated a reluctance to provide feedback to their peers. 
This point was raised in the interviews, where four questions were asked seeking to examine how learners self-reflect upon their sharing practices. Accordingly, interviews were used to identify the reason(s) why learners in this study demonstrated a reluctance to provide peer-feedback. Interview data suggested that learners did not feel comfortable about providing feedback, because it was perceived as potentially offensive, as evidenced by Louisa in the following:

I wouldn't want to offend them by saying oh I think you should have done this or you could have done that I feel uneasy about that to be honest.

(Louisa)

Indeed, learners did not" "like to point the finger at anybody (...) because you [they] value that they have taken time to do something" (Otto). What is more, learners $(n=3)$ felt that they were not entitled to provide peer-feedback as they were not proficient enough in the target language and that discouraged them from doing so. These views are articulated in the following quote:

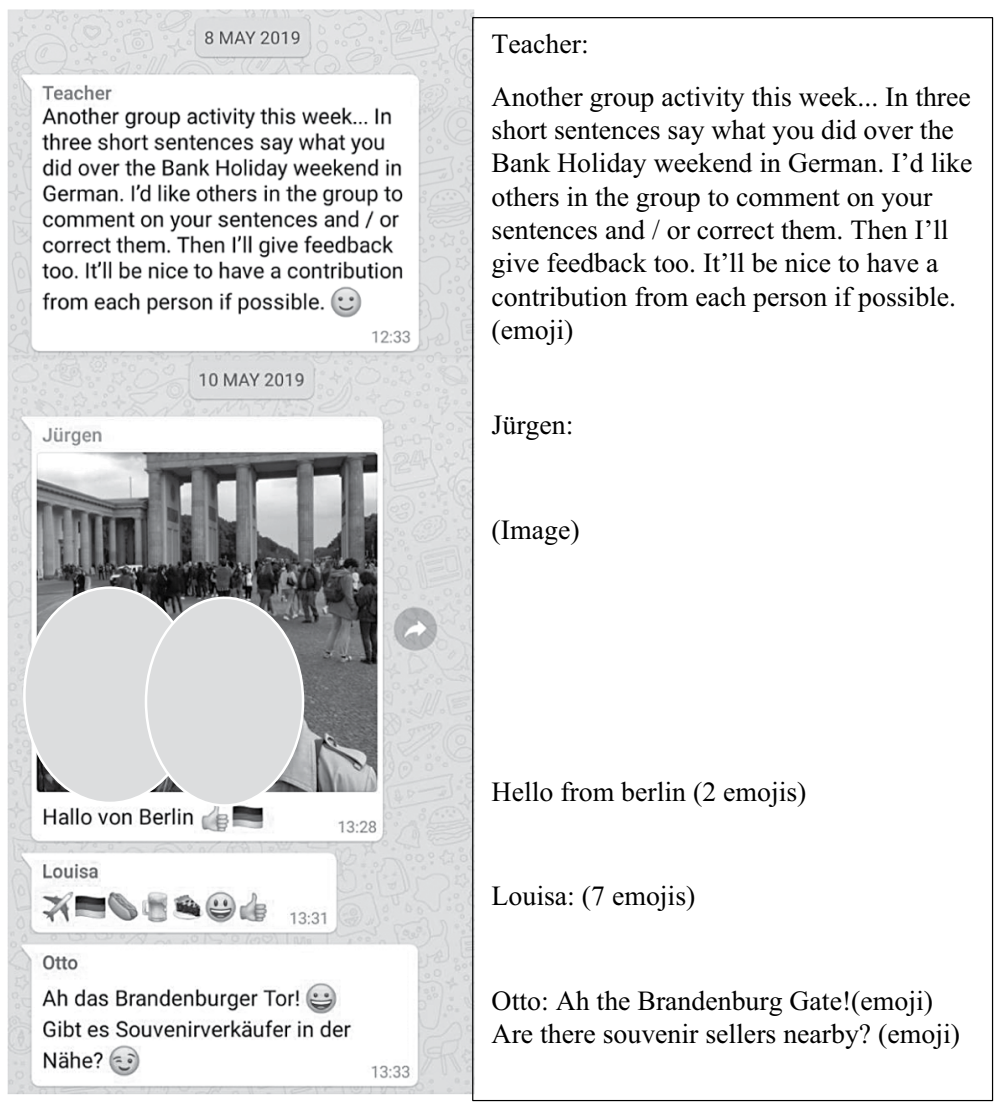

Figure 4.4 Activity involving peer-feedback. 


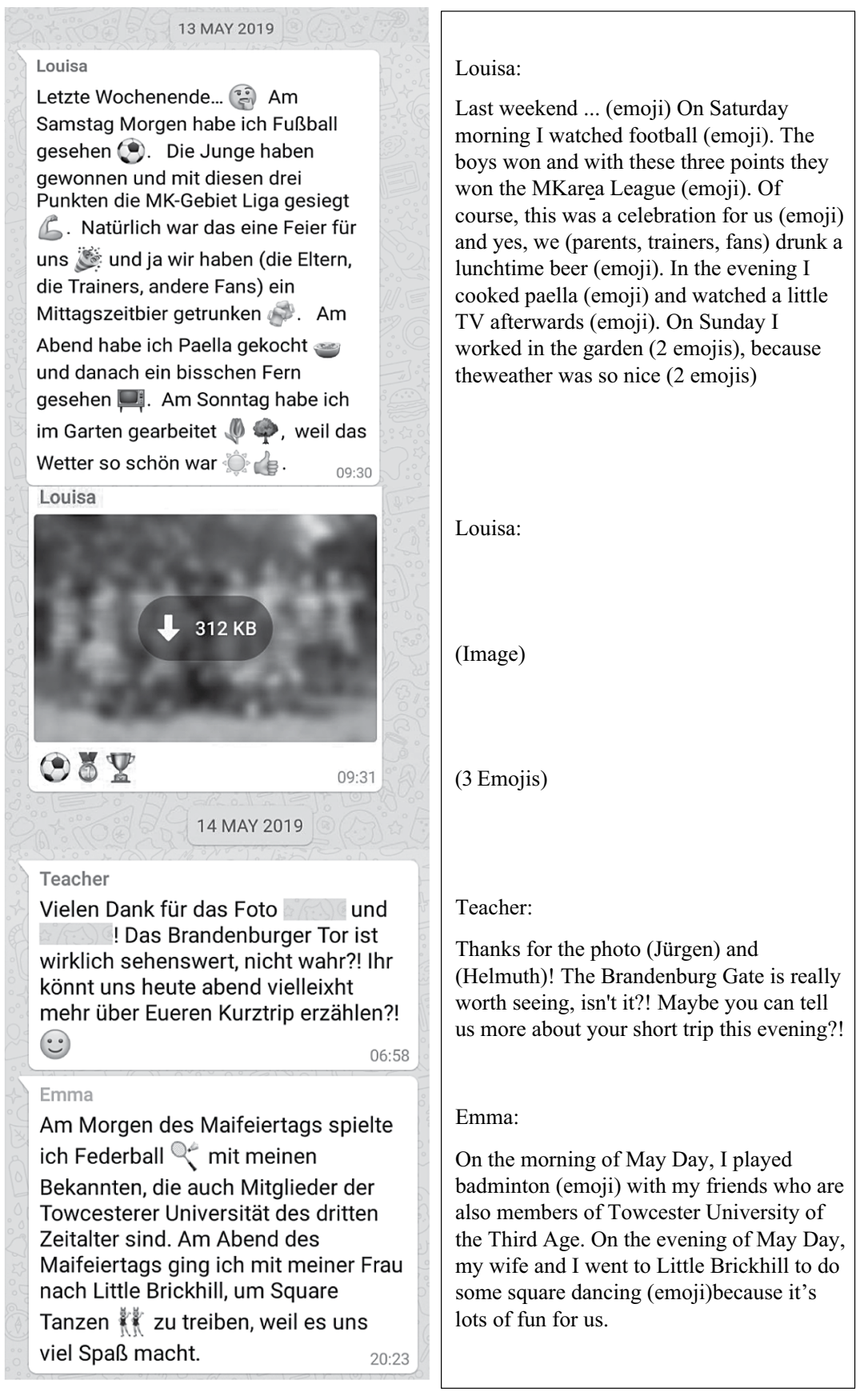

\section{Figure 4.4 (Continued)}


I wouldn't contribute to that because I don't feel that my knowledge is enough to give people feedback.

(Jürgen)

Another reason revealed by the interview data was related to the teacher's role. Specifically, two learners seemed to think that "that's more [name of the teacher]'s role to do that it's a bit uncomfortable sometimes" (Otto), also evidenced in the following:

I was quite happy to suggest things and correct them when we were working through some exercises if they welcomed it or not I don't know but I was very anxious not to undercut [name of the teacher]'s role who is obviously the teacher.

(Emma)

All the above views that emerged from the semi-structured interviews shed light on learners' reluctance to provide feedback to their peers. In what follows, we analysed the communicative events in terms of "selecting", "styling", and "negotiating" as discussed in Section 4.3.3.

\subsubsection{Sharing practices: selecting, styling, negotiating}

The discussion so far has provided three examples of the activities uploaded by the teacher into the WhatsApp group and showed how learners participated in and contributed to these. In terms of selecting, the language learning activities discussed in this study revealed a recurrent pattern in the sense that they all aimed to enhance learners' writing competence and vocabulary acquisition.

As regards styling, it was evident that the activities discussed above involved different entextualisation patterns. Specifically, the first activity (see Section 4.3.3) was introduced using the German language, while the instructions in the other two (see Sections 4.3.4. and 4.3.5) were given in English. The teacher followed the same styling format in all activities $(n=6)$ which required learners to compose sentences using given vocabulary. On the contrary, when sharing activities with a certain degree of complexity (e.g. "Guess the city activity") he styled the instructions using the English language. Moreover, when introducing activities that required learners to provide peer-feedback (see Section 4.3.5), the German teacher used English. The teacher's choice of language in these activities was possibly made to ensure that the learners had understood the language task and what was expected from them.

The next, and most important, level of analysis was "negotiating", which concerned learners' engagement with the shared activities. The communicative events discussed above showed that learners' responses to the uploaded activities generated different degrees of engagement. In the simplest case, learners' participation was limited to responding directly to the teacher (see Section 4.3.3), while on other occasions (see Section 4.3.4) learners were engaged in more substantial ways. More specifically, and in terms of "selecting", those activities which prompted 
learners to reply individually to the teacher's post, and focused on the abstract practice of language form, resulted in no interactions amongst the members of the group. On the contrary, the "Guess the city" activity encouraged learners not only to share their individual responses but also to read their peers' contributions in order to decipher the clues and then provide their answers. This activity also resembled a game (or a quiz) which is rooted in learners' meaningful experience of Germany and necessitates learners to draw on their personal knowledge, share their own interpretation of the clues, negotiate these clues with their peers, and finally reach to the correct answer.

As regards peer-to-peer feedback, and in terms of "negotiating", the discussion above indicated that learners demonstrated a reluctance to engage with such interactions. Apart from the reasons which emerged from the analysis of the interview data, analytic attention should be placed on the "styling" of the instruction in these types of activities. Specifically, as shown in Section 4.3.5, the teacher explicitly asked the learners to comment on their peers' sentences and/ or correct them. The exact same instructions were provided in all activities that required learners to provide feedback to their peers. Moreover, in terms of styling, each of the three activities was divided into two parts. The first part involved the language task prompting learners to reply individually to the activity (e.g. what you did over the Bank Holiday weekend?) and the second part directly asked the learners to comment on or correct their peers' contributions. The design of the tasks prompted learners to provide feedback in an overt way, while the first part of the tasks did not require learners' interaction. Consequently, the selection and the styling of the tasks might have not encouraged learners to engage in such interactions.

Finally, regarding "negotiating", the analysis of the communicative events examined above showed that participants' engagement with the shared activities were not time-bound. Specifically, some interactions in the online environment were synchronous (or near synchronous). For instance, the online exchange discussed in Section 4.3.4 lasted for 41 minutes resulting in a total of six chat entries. This showed that WhatsApp can enable synchronous (or near synchronous) communication and emphasises the potential for immediate interactions in this platform. Nonetheless, in the same activity (Section 4.3.4), participants were sharing their contributions for nine days. Such observations suggest that the MIM application can also afford asynchronous and/or diachronic communication. Moreover, since WhatsApp is an archived online environment, it can enable learners to access previous chat entries retrospectively and re-read as well as decipher what other users had shared. This appears to be a significant benefit of using WhatsApp, since "You can search back (...) you can look back into the Intermediate German Whats App group on your phone or iPad or whatever and you can find the conversation so that was quite good" (Otto). In a traditional in-classroom learning environment, where learners inevitably do not have the chance to archive any interactions, they are not able to access the learning context over time. In this study, the use of WhatsApp allowed learners to access the discussion threads as well as the learning material at any point. 


\subsection{Discussion and moving forward}

The purpose of Chapter 4 was to study patterns of interaction in WhatsApp, exploring the extent to which this MIM application might provide a favourable environment for language learning. Coinciding with Keogh's (2017) study, the findings revealed learners' reactive and limited participation, while the activity in the WhatsApp group heavily relied on the teacher's efforts to initiate conversation. A reason for these participation patterns emerged from the analysis of the interview data. Specifically, learners perceived that only the teacher had the authority to initiate conversation in WhatsApp. Such perceptions and predefined expectations highlight the different dynamics of participating and sharing when using WhatsApp for formal (or non-formal) language learning as compared to informal everyday life use.

As regards the affordances of the platform, this study showed that participants were able to share their contributions without any temporal constraints. Specifically, it was evident from the analysis of the selected communicative events that WhatsApp can afford synchronous (near synchronous), asynchronous and/or diachronic communication. Another important benefit of WhatsApp indicates that the archived nature of the platform enabled participants to retrieve previous chat entries retrospectively and re-read as well as decipher what other users had shared at any point.

The analysis of the communicative events examined in this study suggests that what is being shared (selecting), and how this is done (styling) can influence the ways in which participants engage with the shared content (negotiating). As regards online interaction, other studies (see Aburezeq \& Ishtaiwa, 2013; Andujar, 2016; Keogh, 2017) emphasised that WhatsApp can encourage language interaction among participants. Notwithstanding that this MIM application can afford language interaction, this study showed that learners' participation and interaction cannot be ensured by the mere use of the platform, but heavily relies on task design. Moreover, the effective selection and the styling of the language activities can potentially stimulate other interactions, such as peer-to-peer feedback.

Therefore, we argue that the educational value of this MIM application and its appropriateness as a teaching and learning environment need to be further investigated. Future research should aim to establish a clear theoretical framework for the integration of WhatsApp into the language classroom by developing transparent guidelines and pedagogical strategies which can lead to an effective use of the medium for language teaching and learning purposes.

\subsection{Implications for practice}

Chapter 4 explored the use of WhatsApp by a group of adult learners of German language and their teacher in an adult education centre. The findings suggest that the mere use of WhatsApp cannot guarantee language interaction among participants. Moreover, inflated expectations that WhatsApp can generate more interaction in language settings because of its communicative use in everyday life are 
questioned. Consequently, current pedagogical practices cannot be reformed simply by exploiting the familiarity and popularity of this MIM application. WhatsApp can afford online language interactions and might effectively facilitate language learning, but this necessitates extensive training of educators to use the medium to its full potential. Therefore, practitioners should consider the process of planning, designing, structuring, and implementing educational activities in WhatsApp and should not simply assume that the use of WhatsApp will magically increase learners' participation and interaction.

\section{References}

Aburezeq, I. M., \& Ishtaiwa, F. F. (2013). The impact of WhatsApp on interaction in an Arabic language teaching course. International Journal of Arts \& Sciences, 6(3), 165-180.

Ahmed, S. S. (2019). WhatsApp and learn English: a study of the effectiveness of WhatsApp in developing reading and writing skills in English. ELS Journal on Interdisciplinary Studies in Humanities, 2(2), 148-156. https://doi.org/10.34050/els-jish.v2i2.6419

Alzubi,A.A. F., \& Singh, M. K. M. (2018). The impact of social strategies through smartphones on the Saudi learners socio-cultural autonomy in EFL reading context. International Electronic Journal of Elementary Education, 11(1), 31-40. https://doi.org/10.26822/iejee.2018143958

Androutsopoulos, J. (2014). Moments of sharing: entextualization and linguistic repertoires in social networking. Journal of Pragmatics, 73, 4-18. doi:10.1016/j.pragma.2014.07.013

Androutsopoulos, J. (2015). Networked multilingualism: some language practices on Facebook and their implications. International Journal of Bilingualism, 19(2), 185-205. doi:10.1177/1367006913489198

Andujar, A. (2016). Benefits of mobile instant messaging to develop ESL writing. System, 62, 63-76. doi:10.1016/j.system.2016.07.004

Braun,V., \& Clarke,V. (2006). Using thematic analysis in psychology. Qualitative Research in Psychology, 3(2), 77-101. doi:10.1191/1478088706qp063oa

Cho, H. (2017). Synchronous web-based collaborative writing: Factors mediating interaction among second-language writers. Journal of Second Language Writing, 36, 37-51. doi:10.1016/j.jslw.2017.05.013

Chua, S. M. (2022). Discourse practices in MOOC discussions: a corpus linguistic approach. In B. Rienties, R. Hampel, E. Scanlon, \& D. Whitelock (Eds.), Open world learning: research, innovation and the challenges of high-quality education, pp. 76-88. London: Routledge.

Church, K., \& de Oliveira, R. (2013). What's up with whatsapp? comparing mobile instant messaging behaviors with traditional SMS. Proceedings of the 15th International Conference on HumanComputer Interaction with Mobile Devices and Services, 352-361. doi:10.1145/ 2493190.2493225

Conde Gafaro, B. (2022). First steps towards self-regulated learning: setting goals in MOOCs. In B. Rienties, R. Hampel, E. Scanlon, \& D. Whitelock (Eds.), Open world learning: research, innovation and the challenges of high-quality education, pp. 63-75. London: Routledge.

Fauzi, I., \& Angkasawati, P. (2019). THE use of listening logs through WhatsApp in improving listening comprehension of EFL students. JOALL (Journal of Applied Linguistics \& Literature), 4(1), 13-26. https://doi.org/10.33369/joall.v4i1.6773

Iwaniec-Thompson, G. (2022). The identity trajectories of older academics: workplace affordances and individual subjectivities. In B. Rienties, R. Hampel, E. Scanlon, \& D. Whitelock (Eds.), Open world learning: research, innovation and the challenges of high-quality education, pp. 250-263. London: Routledge. 
John, N. A. (2013). Sharing and Web 2.0: the emergence of a keyword. New Media \& Society, 15(2), 167-182. doi:10.1177/1461444812450684

Kartal, G. (2019). What's up with WhatsApp? A critical analysis of mobile instant messaging research in language learning. International Journal of Contemporary Educational Research, 6(2), 352-365. https://doi.org/10.33200/ijcer.599138

Keogh, C. (2017). Using WhatsApp to create a space of language and content for students of international relations. Latin American Journal of Content $\mathcal{E}$ Language Integrated Learning, 10(1), 75-104. doi:10.5294/laclil.2017.10.1.4

Lai, A. (2016). Mobile immersion: an experiment using mobile instant messenger to support second-language learning. Interactive Learning Environments, 24(2), 277-290. doi:10.1080/ 10494820.2015.1113706

Mackey, A., Abbuhl, R., \& Gass, S. M. (2012). Interactionist approach. In S. M. Gass, \& A. Mackey (Eds.), The routledge handbook of second language acquisition, pp. 7-23. London: Routledge.

Srisontisuk, P. (2022). Practitioner's perspective on young children's use of mobile technology. In B. Rienties, R. Hampel, E. Scanlon, \& D. Whitelock (Eds.), Open world learning: research, innovation and the challenges of high-quality education, pp. 225-236. London: Routledge.

Statista. (2020). Number of monthly active WhatsApp users worldwide from April 2013 to March 2020. https://www.statista.com/statistics/260819/number-of-monthly-active-whatsappusers/ 